\title{
Pharmaceutical prevention strategy for arteriovenous fistula and arteriovenous graft failure
}

\author{
Hiroyuki Tsukada, Motonobu Nakamura*, Tomohito Mizuno, Nobuhiko Satoh and Masaomi Nangaku
}

\begin{abstract}
Vascular access failure (VAF) is a critical problem in patients undergoing hemodialysis (HD). Importantly, VAF impairs the quality of life in patients undergoing HD while imposing high medical costs. A variety of strategies (e.g., endovascular therapy and surgical reconstruction) for treating VAF have been established. However, strategies for preventing VAF are scarce. In this review, we summarized the available literatures regarding the prevention of VAF in patients undergoing HD with a focus on arteriovenous fistulas and arteriovenous grafts. This review proposes the following three aspects for developing strategies for preventing VAF: (i) early identification of risk factors of VAF (e.g., preoperative vascular conditions, age, sex, ethnicity, and clinical backgrounds), (ii) prophylactic drugs to reduce the risk of VAF, and (iii) early VAF detection through monitoring and surveillance of vascular access, particularly at frequent stenotic sites. A few prophylactic drugs may effectively prevent VAF based on the patient's clinical background. A few prophylactic drugs may effectively prevent VAF based on the patient's clinical background; however, currently, there is no strong evidence on the efficacy of these drugs in reducing the incidence of VAF. Thus, additional large, randomized controlled studies are warranted to establish effective strategies for preventing VAF.
\end{abstract}

Keywords: Arteriovenous fistula, Arteriovenous grafts, Hemodialysis, Vascular access failure, Prevention of vascular access failure, Prophylactic drugs

\section{Background}

HeHemodialysis (HD) is one of major modality of renal replacement therapy (RRT), and approximately 1.5 million patients worldwide have end-stage renal disease (ESRD) and require HD [1]. In addition, vascular access failure (VAF) is becoming a critical problem in the maintenance of HD. Although the pathogenesis of VAF has not been completely elucidated, it has been hypothesized to be caused by enhanced smooth muscle cell migration and proliferation [2,3], shear stress generated by turbulent blood flow $[4,5]$, excessive mechanical stretching due to a mismatch in elastic properties around the site of anastomosis [6], and oxidants secreted by activated platelets and inflammatory cells [7].

In this context, an efficiently functioning vascular access (VA) is crucial for patients undergoing HD.

\footnotetext{
* Correspondence: nakamura-stm@umin.ac.jp

Division of Nephrology and Endocrinology, The University of Tokyo Hospital, 7-3-1 Hongo, Bunkyo-ku, Tokyo 113-8655, Japan
}

Regarding the type of vascular access (VA) to be used in HD, the Japanese Society for Dialysis Therapy (JSDT) guidelines state that the arteriovenous fistula (AVF) approach is advantageous compared to AVG owing to its durability, low risk of infection, and reduced need for intervention; however, recently, the focus has slightly shifted toward personalizing the type of VA to be used [8]. The Kidney Diseases Outcomes Quality Initiative (K/DOQI) and European Renal Best Practice (ERBP) Guidelines also promote the AVF approach and discourage the use of catheters $[9,10]$. Following this recommendation, the use of the AVF approach increased drastically in the United States (US), with $62.8 \%$ of patients undergoing HD in a year, according to the United States Renal Data System (USRDS) data in 2018 [10]. Furthermore, JSDT guidelines recommend that arteriovenous grafts (AVGs) should be the second choice if the patient has no superficial native vessels that can be used for anastomosis in AVFs.

(C) The Author(s). 2019 Open Access This article is distributed under the terms of the Creative Commons Attribution 4.0 International License (http://creativecommons.org/licenses/by/4.0/), which permits unrestricted use, distribution, and 
VAF impairs the quality of life of patients with HD and imposes considerable medical costs. For instance, the annual expenditure associated with VA is more than $\$ 1$ billion in the US alone [11, 12]. While the treatment of VAF is relatively well-established (e.g., endovascular therapy and surgical reconstruction), little is known regarding the strategies for preventing VAF. In this study, we review the available literature on strategies for preventing VAF in HD with a focus on AVFs and AVGs.

\section{Main text}

\section{Definition of VAF}

The definitions of VAF vary slightly throughout the literature and published guidelines. In this review, VAF is defined in accordance with the indication of VA treatment recommended by JSDT guidelines. Accordingly, VA was indicated in more than 50\% stenosis or thrombosis along with one or more of the following clinical medical abnormalities: (i) decreased blood flow $(<500 \mathrm{ml} / \mathrm{min}$ in AVFs or $<650 \mathrm{ml} / \mathrm{min}$ in AVGs), (ii) increased venous pressure, (iii) abnormally high blood urea nitrogen level, and (iv) unexplained reduction in dialysis efficiency [8].

\section{Risk factors of VAF}

Several risk factors of VAF (Table 1) have been widely reported.

\section{Age}

Reportedly, the proportion of elderly patients $>65$ years of age receiving RRT was $66 \%, 40 \%$, and $42 \%$ in Japan (2016), the US (2016), and Europe (2015), respectively $[10,13,14]$. However, there are conflicting data on whether older age is a risk factor for AVF maturation. A recent review focusing on VA in elderly patients undergoing HD demonstrated that older age is one of the risk factors for AVF maturation failure [14, 15]. Moreover, a prospective study involving 176 patients revealed that elderly patients $\geq 65$ years of age with diabetes exhibited a markedly increased risk of VAF [16]. In addition, a prospective study on 422 patients, aiming to identify patient profiles associated with the failure of AVF maturation, revealed that an age of $\geq 65$ years was an

\section{Table 1 Risk factors for VAF}

\footnotetext{
- Demographic factors

- Age, sex, ethnicity

- Clinical factors

- Cardiac disease, peripheral arterial disease, diabetes mellitus, obesity

- Hemodynamic factors

- Size and diastolic function of vessels, blood flow

- Technical factors

- experience of surgeon and cannulation techniques during dialysis

VAF vascular access failure
}

independent risk factor of VAF [odds ratio (OR) 2.23; 95\% confidence interval (95\% CI), 1.25-3.96] [17]. In contrast, a multicenter prospective study on 395 patients undergoing $\mathrm{HD}$ demonstrated that an age of $\geq 65$ years was not associated with the primary functional loss of AVF patency [hazard ratio (HR) 1.49, 95\% CI 0.96-2.31] [18]. Further, a recent retrospective study on 525 patients who underwent AVF constructions and who were stratified by age $(<65,65-75$, and $>75$ years $)$ revealed that no significant differences in the incidence of primary VAF or primary patency after $1-3$ years [19]. These findings suggested that VAF occurs frequently in elderly patients because the blood flow of AVF in the elderly was lower than that in non-elderly patients possibly due to atherosclerosis with aging $[14,15,20]$.

\section{Sex}

The role of sex as a risk factor of VAF is controversial. A multicenter prospective study on 395 patients undergoing HD revealed that sex was not associated with primary functional AVF patency loss (HR 1.52, 95\% CI 0.99-2.34) [18]. However, several reports showed that female sex is one of the risk factors of VAF. According to the USRDS data in 2018, AVF maturation time was longer in females than that in males (128 vs. 116 days), and the rate of AVF maturation failure was higher in females than that in males $(45.1 \%$ vs. $34.2 \%)$ [10]. Moreover, a retrospective study on 444 patients showed that males had a lower risk of VAF (HR $0.63,95 \%$ CI $0.44-0.91$ ) [21]. Similarly, another retrospective study on 205 patients showed that female sex was a significant risk factor of AVF maturation failure (HR 2.42, 95\% CI 1.324.45) [22]. In addition, a prospective study involving 360 elderly patients undergoing HD ( $\geq 67$ years) clearly demonstrated that female sex was associated with VAF (OR 1.69, 95\% CI 1.55-1.83) [23]. Although the reasons for these differences based on sex have not been clarified, a review on VA noted that vessel diameter is generally smaller in females than that in males and that this difference may be associated with AVF maturation failure in females [24].

\section{Ethnicity}

Race and ethnicity differences may be significant risk factors of AVF maturation failure. According to the USRDS 2018 data regarding race differences, black population had the highest rate of AVF maturation failure $(42.0 \%)$. A recent retrospective study reported that the rate of AVF maturation failure was higher in non-Hispanics than that in Hispanics (39.7\% vs. 33.8\%) [10]. Although an observational study showed that the AVF adequacy rate was not influenced by patient race, other studies have demonstrated race or ethnicity as a risk factor of VAF or AVF maturation failure $[17,23,25-28]$. These findings 
suggested racial or ethnic differences in the incidence rate of VAF. Here are some reasons to consider in racial differences such as racial differences in prevalence of arteriosclerosis [29], gene expression differences regarding hypertension [30], racial differences in oxidative stress and inflammation [31] or racial difference in endothelial function [32].

\section{Comorbid conditions}

Clinical comorbidities such as coronary artery disease (CAD), peripheral arterial disease (PAD), diabetes mellitus, and obesity have been reported as risk factors of VAF in patients undergoing HD.

CAD In a retrospective study, 1618 patients undergoing HD in Taiwan were categorized into two groups: early $(<1$ year) and late ( $>1$ year) loss of primary functional patency, based on intervention-free intervals. In an analysis of demographic and clinical characteristics, patients who exhibited an early loss of primary functional patency showed higher proportions of CAD $(P=0.02)$ [33]. A prospective study on 422 patients revealed that CAD was an independent risk factor for AVF maturation failure (OR 2.83, 95\% CI 1.60-5.00) [17]. Interestingly, a recent study demonstrated that increasing the mean platelet volume (MPV)/platelet count ratio, previously identified as an independent predictor of 4-year mortality following myocardial infarction [34], was useful for predicting VAF [35].

PAD A review reported that the inflow artery was required to increase the baseline blood flow by $10-20$ times as well as to deliver the necessary blood volume to AVF to ensure a functional AVF [36]. PAD can increase the risk of VAF by interfering with the increase in blood volume to AVF because arteries affected by PAD can fail to sufficiently dilate due to intimal hyperplasia and arterial calcification. An observational retrospective study on 784 incident patients undergoing HD showed that a history of PAD increased the risk of VAF by $24 \%$ [37]. Interestingly, a prospective study on 422 patients revealed that PAD was an independent risk factor of AVF maturation failure (OR 2.97, 95\% CI 1.34-6.57) [17]. Furthermore, a retrospective study on 111 patients undergoing HD showed that an ankle-brachial index (ABI) of $<0.9$ was significantly associated with VAF and that $\mathrm{ABI}$ could potentially identify patients at a high risk of VAF [38].

Diabetes mellitus Patients' glycemic states should be evaluated before VA construction because glycemic state abnormality can cause wound infection or delayed wound healing. Moreover, diabetes mellitus is generally considered a risk factor of CVDs. However, several studies regarding VA have suggested that diabetic state alone does not affect VAF when adjusted for potential confounders, such as CAD, PAD, and obesity [16, 39-42].

Obesity According to the results of a retrospective cohort study that used the USRDS Dialysis Morbidity and Mortality Wave II dataset, obesity was associated with poor AVF maturation in patients in the highest body mass index (BMI) quartile $\left(\geq 35 \mathrm{~kg} / \mathrm{m}^{2}\right)$ (OR $3.66,95 \%$ CI 1.27 10.55, $P=0.017$ ) [42]. Furthermore, in another study on 183 AVFs comparing obese patients with non-obese patients, the likelihood of AVF construction and primary patency rates were almost equal between the groups. However, secondary patency rates of AVFs were significantly lower in obese patients (HR 2.93, 95\% CI 1.44-5.93, $P=0.004$ ) than those in non-obese patients (HR 1.13, 95\% CI $0.42-3.06, P=0.80$ ) [43]. A case report suggested that in the adducted position, soft tissue compression of the venous outflow of the upper extremity causes reduced secondary patency that is observed in obese patients [44].

\section{Prevention of VAF}

The prevention of VAF is crucial for all healthcare providers involved in RRT. This review proposed the prevention of VAF based on the following criteria: (i) preoperative examination, (ii) prophylactic drugs for VAF, and (iii) maintenance of VA by monitoring and surveillance.

\section{Preoperative examination}

Physical examination Physical examination of VA in patients undergoing HD is an essential skill that all healthcare providers directly directly involved in HD must inculcate. Before surgery, any history of any central venous catheters or pacemaker should be confirmed [45]. In addition, clinicians should carefully assess for signs of venous hypertension, such as prominent and tortuous collateral veins around the shoulder and upper limb edema, in the limb undergoing surgery. Particularly, obese patients typically exhibit a thick subcutaneous adipose tissue layer in their extremities; thus, VAF or AVF maturation failure can occur in such patients due to the venous depth. A salvage operation to retrieve the AVF could be useful in obese patients when AVF is located deep in the skin [46]. Alternatively, several studies have suggested that lipectomy or liposuction can prove useful to allow a functional AVF construction in obese arms [47-50].

Differential blood pressures To check for arterial stenosis, the difference in the blood pressures of the two upper arms can be useful because arterial inflow insufficiency is a risk factor of VAF or AVF maturation failure; 
this difference in blood pressures was suggested to be useful by a review [51]. According to the clinical guidelines of the Society for Vascular Surgery, arterial stenosis commonly occurs as an orifical stenosis of the subclavian artery caused by atherosclerosis. In addition, the guidelines recommend the patient should undergo access viability evaluation and risk stratification before undergoing arterial stenosis management.

Allen test The Allen test is used to evaluate the blood supply to the hand. The presence of adequately functioning dual circulation to the hand, which is represented by the radial and ulnar arteries that distally communicating through the palmar arches, is a crucial protective mechanism against hand ischemia. In addition, the use of pulse oximetry as an aid to the Allen test has been reported to provide added information regarding collateral hand circulation [52].

Preoperative vascular imaging The low quality of the available vessels for VA construction is reportedly the most critical risk factor of VAF. Thus, preoperative arterial and venous evaluation, known as "vascular imaging," is crucial for predicting VAF or AVF maturation failure. JSDT guidelines recommend that an ultrasound examination is preferred to preoperatively evaluate vessels rather than to rely on physical examination alone [8]. Non-invasive ultrasound examination can provide detailed preoperative information regarding vascular qualities, vessel diameters, and vessel depth.

Arterial imaging Several studies have reported that the smallest diameter of the radial artery that is required for successful radiocephalic AVF construction is 1.5$2.0 \mathrm{~mm}$ [53-55]. However, arterial diameter is not the sole indicator of successful AVFs construction; wall thickness and function must be assessed during arterial evaluation. In the Hemodialysis Fistula Maturation Study, patients who were enrolled from seven clinical centers underwent up to five preoperative vascular function tests. As a result, increased nitroglycerin-mediated dilation or flow-mediated dilation was associated with significantly greater AVF blood flow rates and AVF diameters after 6 weeks. These findings illustrate the importance of evaluating the intrinsic ability of arterial dilation before AVF construction [56].

Venous imaging The incidence of VAF is much higher in veins than that in arteries because of venipuncture required for each HD session. In addition, several studies reported structural abnormalities in patients with ESRD, regardless of AVF constructions $[57,58]$.

Regarding veins, a clinical study demonstrated that a venous luminal diameter of $\geq 2.5 \mathrm{~mm}$ and of $\geq 4.0 \mathrm{~mm}$ is essential for AVF and AVG, respectively; additionally, the continuity of distal superficial veins in the forearm is essential [59]. Furthermore, several reports have emphasized the importance of evaluating vein distensibility before AVF construction [59-61]. Evaluating venous dilatation involves the inflation of the blood pressure cuff or the use of a tourniquet above the vein so that the vein can dilate at least $50 \%$ of the remaining inner diameter [61].

\section{Drugs for VAF prophylaxis}

Several studies have investigated the effectiveness of drugs for VAF prophylaxis during the perioperative period; the drugs studies mainly include cardiovascular drugs such as antiplatelet drugs [62-71], anticoagulant drugs [72-74], statins [75-79], fish oil [68, 80, 81], and antihypertensive drugs [82-85].

Antiplatelet drugs As shown in Table 2 and Table 3, the effect of antiplatelet drugs on VAF has been

Table 2 The association of antiplatelet drugs with VAF for AVF

\begin{tabular}{|c|c|c|c|c|c|c|}
\hline Author & Design & N (Control) & Exposure Timing & Outcome (duration) & VAF development & $\begin{array}{l}\text { Number of Bleeding } \\
\text { events (Control) }\end{array}$ \\
\hline $\begin{array}{l}\text { Gröntoft } \\
\text { et al [71] }\end{array}$ & Placebo-controlled & $258(124)$ & $\begin{array}{l}\text { Ticlopidine } \\
250 \mathrm{mg} 2 \times / \text { day } \\
\text { Pre }\end{array}$ & AVF thrombosis (28 days) & $\begin{array}{l}\text { Equivalent risk } \\
(12 \% \text { vs. } 19 \%, P=0.101)\end{array}$ & None \\
\hline $\begin{array}{l}\text { Dember } \\
\text { et al [70] }\end{array}$ & Placebo-controlled & $877(436)$ & $\begin{array}{l}\text { Clopidgrel } \\
75 \text { mg/day } \\
\text { (loading } 300 \text { mg) } \\
\text { Pre }\end{array}$ & $\begin{array}{l}\text { AVF suitable for HD } \\
\text { (150-180 days) }\end{array}$ & $\begin{array}{l}\text { Equivalent risk } \\
(61.8 \% \text { vs. } 59.5 \%, \text { RR } 1.05,95 \% \\
\text { Cl } 0.94-1.17, P=0.40)\end{array}$ & $\begin{array}{l}12 \\
(13) \\
\text { NS }\end{array}$ \\
\hline $\begin{array}{l}\text { Ghorbani } \\
\text { et al [69] }\end{array}$ & Placebo-controlled & $93(47)$ & $\begin{array}{l}\text { Clopidogrel } \\
75 \text { mg/day } \\
\text { Pre }\end{array}$ & $\begin{array}{l}\text { Primary AVF failure } \\
(2 \text { months })\end{array}$ & $\begin{array}{l}\text { Lower risk } \\
(21.6 \% \text { vs. } 5.2 \%, \text { RR } 0.72,95 \% \\
\text { Cl } 0.41-1.01, P=0.03)\end{array}$ & None \\
\hline Irish et al [68] & Placebo-controlled & $406(203)$ & $\begin{array}{l}\text { Aspirin } \\
100 \mathrm{mg} / \text { day } \\
\text { Pre }\end{array}$ & $\begin{array}{l}\text { Primary AVF failure } \\
\text { (12 months) }\end{array}$ & $\begin{array}{l}\text { Equivalent risk } \\
\text { (45\% vs. 43\%, RR 1.05, 95\% } \\
\text { Cl 0.84-1.31, P = 0.68) }\end{array}$ & $\begin{array}{l}10 \\
(16) \\
\text { NS }\end{array}$ \\
\hline
\end{tabular}


Table 3 The association of antiplatelet drugs with VAF for AVG

\begin{tabular}{|c|c|c|c|c|c|c|}
\hline Author & Design & $\begin{array}{l}\mathrm{N} \\
\text { (Control) }\end{array}$ & Exposure Timing & Outcome (duration) & VAF development & $\begin{array}{l}\text { Number of Bleeding } \\
\text { events (Control) }\end{array}$ \\
\hline $\begin{array}{l}\text { Harter } \\
\text { et al [66] }\end{array}$ & $\begin{array}{l}\text { Placebo- } \\
\text { controlled }\end{array}$ & $44(N A)$ & $\begin{array}{l}\text { Aspirin } \\
160 \mathrm{mg} / \text { day } \\
\text { NA }\end{array}$ & AVG thrombosis (5 months) & $\begin{array}{l}\text { Lower risk } \\
(32 \% \text { vs. } 72 \% \\
P<0.01)\end{array}$ & NA \\
\hline $\begin{array}{l}\text { Sreedhara } \\
\text { et al [65] }\end{array}$ & $\begin{array}{l}\text { Placebo- } \\
\text { controlled }\end{array}$ & $53(24)$ & $\begin{array}{l}\text { Dipyridamole } \\
225 \text { mg } 3 \times / \text { day } \\
\text { Pre }\end{array}$ & AVG thrombosis (18 months) & $\begin{array}{l}\text { Lower risk } \\
(42 \% \text { vs. } 80 \% \text {, RR } 0.35 \\
P=0.02)\end{array}$ & $\begin{array}{l}2 \\
(5) \\
\text { NS }\end{array}$ \\
\hline $\begin{array}{l}\text { Kaufman } \\
\text { et al [64] }\end{array}$ & $\begin{array}{l}\text { Placebo- } \\
\text { controlled }\end{array}$ & $200(96)$ & $\begin{array}{l}\text { Clopidogrel } \\
75 \mathrm{mg} / \text { day } \\
+ \text { Aspirin } \\
325 \mathrm{mg} / \text { day } \\
\text { Post }\end{array}$ & $\begin{array}{l}\text { AVG thrombosis } \\
\text { (stopped by bleeding risk) }\end{array}$ & $\begin{array}{l}\text { Equivalent risk } \\
\text { (HR 0.81, } 95 \% \\
\text { Cl } 0.47-1.40, P=0.45)\end{array}$ & $\begin{array}{c}38 \\
(67) \\
P=0.006\end{array}$ \\
\hline $\begin{array}{l}\text { Trimarchi } \\
\text { et al [63] }\end{array}$ & $\begin{array}{l}\text { Placebo- } \\
\text { controlled }\end{array}$ & $19(8)$ & $\begin{array}{l}\text { Clopidogrel } \\
75 \text { mg/day } \\
\text { Post }\end{array}$ & Time to AVG thrombosis & $\begin{array}{l}\text { Lower risk } \\
\text { (350 vs. } 86 \text { days, } \\
P<0.001)\end{array}$ & None \\
\hline $\begin{array}{l}\text { Dixon } \\
\text { et al [61] }\end{array}$ & $\begin{array}{l}\text { Placebo- } \\
\text { controlled }\end{array}$ & 649 (328) & $\begin{array}{l}\text { Dipyridamole } 400 \text { mg } 2 \times \\
\text { /day } \\
+ \text { Aspirin } \\
50 \text { mg } 2 \times \text { /day } \\
\text { Post }\end{array}$ & $\begin{array}{l}\text { Primary patency rates of AVG } \\
\text { ( } 4.5 \text { years) }\end{array}$ & $\begin{array}{l}\text { Lower risk } \\
\text { (HR 0.82, 95\% } \\
\text { Cl } 0.68-0.98, P=0.03)\end{array}$ & $\begin{array}{l}40 \\
(37) \\
\text { NS }\end{array}$ \\
\hline
\end{tabular}

$V A F$ vascular access failure, $A V G$ arteriovenous graft, $R R$ relative risk, $H R$ hazard ratio, $C /$ confidential interval, NS not significant, NA not available, Pre pre-operative period, Post post-operative period

controversial. Our recent retrospective observational study supported the use of antiplatelet drugs for the prevention of VAF [86].

Aspirin The effect of aspirin on VAF has been controversial. A multicenter study randomly assigned 406 patients to receive either aspirin (100 mg daily) or placebo for 12 weeks before AVF construction. At the 12-month follow-up, the risk of VAF was similar between the aspirin and placebo groups [ $45 \%$ vs. $43 \%$; relative risk (RR) 1.05, 95\% CI 0.84-1.31, $P=0.68$ ] [68] (Table 2).

Regarding AVGs, the results of a multicenter study suggested that dipyridamole plus aspirin improved primary patency. In this study, 649 patients were randomly assigned to receive aspirin (25 mg twice daily) plus extended-release dipyridamole (200 mg twice daily) or placebo after AVG construction. The results showed that aspirin plus dipyridamole was associated with a modest but significant increase in the primary unassisted patency rates (HR 0.82, 95\% CI 0.68-0.98, $P=0.03$ ). Both groups demonstrated an equal incidence of adverse events (particularly bleeding), AVG failure, and death. Furthermore, the incidence of bleeding events in the aforementioned study associated with aspirin plus dipyridamole may have been lower than the anticipated incidence; however, patients at a high risk of bleeding were excluded from the study. Thus, this finding may have been biased [62] (Table 3).

Clopidogrel The effect of clopidogrel on VAF has also been controversial. In a multicenter randomized study on 877 patients who received clopidogrel (300 mg load followed by $75 \mathrm{mg}$ daily) before AVF construction showed reduced rates of early VAF due to thrombosis. However, clopidogrel did not affect the proportion of functional AVFs (61.8\% vs. 59.5\%; RR 1.05, 95\% CI 0.941.17, $P=0.40$ ) [70] (Table 2).

Regarding AVGs, a prospective study on 19 patients showed that clopidogrel (75 mg daily) administered after AVG construction reduced the number of thrombotic episodes and prolonged the time to AVG failure (350 vs. 86 days, $P<0.001$ ) [63]. However, a multicenter, randomized study on 200 patients evaluating the effectiveness of aspirin (325 mg daily) plus clopidogrel (75 mg daily) versus placebo in preventing AVG thrombosis after AVG construction demonstrated that aspirin plus clopidogrel did not prevent AVG thrombosis (HR 0.81, 95\% CI 0.47-1.40, $P=0.45$ ); however, whereas this treatment increased the frequency of bleeding events. The study was discontinued due to the doubled risk of bleeding among those receiving aspirin plus clopidogrel (HR 1.98, 95\% CI 1.19-3.28) [64] (Table 3).

Ticlopidine The effect of ticlopidine on VAF could be limited. In a multicenter, randomized study on 258 patients, ticlopidine (250 mg twice daily) before AVF construction did not significantly reduce AVF thrombosis compared with placebo (12\% vs. $19 \% ; P=0.101)$ [71] (Table 2).

Cilostazol Cilostazol could be effective for the prevention of VAF on AVF. In a retrospective study on 149 patients, 33 received cilostazol for $\geq 30$ days before AVF construction and continued cilostazol therapy for $\geq$ 60 days postoperatively. The matched control group 
Table 4 The association of anticoagulant drugs with VAF

\begin{tabular}{|c|c|c|c|c|c|c|}
\hline Author & Design & $\begin{array}{l}\mathrm{N} \\
\text { (Control) }\end{array}$ & $\begin{array}{l}\text { Exposure } \\
\text { Timing }\end{array}$ & Outcome (duration) & VAF development & $\begin{array}{l}\text { Number of Bleeding } \\
\text { events (Control) }\end{array}$ \\
\hline $\begin{array}{l}\text { Crowther } \\
\text { et al [74] }\end{array}$ & $\begin{array}{l}\text { Placebo- } \\
\text { controlled }\end{array}$ & $107(51)$ & $\begin{array}{l}\text { Warfarin } \\
\text { Low-dose } \\
\text { (INR 1.4-1.9) } \\
\text { Post }\end{array}$ & Time to AVG failure & $\begin{array}{l}\text { Equivalent risk (199 vs. } 83 \text { days, } \\
\text { NS) }\end{array}$ & $\begin{array}{l}0 \\
(6) \\
P=0.03\end{array}$ \\
\hline $\begin{array}{l}\text { Bhomi } \\
\text { et al [73] }\end{array}$ & $\begin{array}{l}\text { Placebo- } \\
\text { controlled }\end{array}$ & $50(25)$ & $\begin{array}{l}\text { Heparin } \\
5000 \text { IU i.v } \\
\text { Peri }\end{array}$ & $\begin{array}{l}\text { Primary patency rates of } \\
\text { AVF } \\
\text { ( } 6 \text { weeks })\end{array}$ & $\begin{array}{l}\text { Equivalent risk ( } 96 \% \text { vs. } 92 \% \text {, } \\
P=0.46)\end{array}$ & $\begin{array}{l}0 \\
(12) \\
P<0.01\end{array}$ \\
\hline $\begin{array}{l}\text { D'Ayala } \\
\text { et al [72] }\end{array}$ & $\begin{array}{l}\text { Placebo- } \\
\text { controlled }\end{array}$ & $115(58)$ & $\begin{array}{l}\text { Heparin } \\
5000 \text { IU i.v } \\
\text { Peri }\end{array}$ & $\begin{array}{l}\text { Primary patency rates of VA } \\
\text { ( } 30 \text { days) }\end{array}$ & $\begin{array}{l}\text { Equivalent risk ( } 84 \% \text { vs. } 86 \% \\
P=0.79)\end{array}$ & $\begin{array}{l}1 \\
(13) \\
P=0.008\end{array}$ \\
\hline
\end{tabular}

VAF vascular access failure, VA vascular access, AVF arteriovenous fistula, AVG arteriovenous graft, NS not significant, Peri peri-operative period, Post post-operative period, i.v intravenous

included 116 patients who underwent the same procedure but did not receive cilostazol during AVF construction. The results showed that the cilostazol group was more likely to attain AVF maturation than the control group (88\% vs. $66 \%$; RR 3.8, 95\% CI 1.3-11.6); moreover, the cilostazol group was more likely to experience a longer time to VAF than the control group (903 vs. 381 days, $P=0.001$ ) [67] (Table 2).

Anticoagulant drugs As shown in Table 4, the effect of anticoagulant drugs on VAF could be limited. In two randomized studies, systemic anticoagulation therapy, comprising $5000 \mathrm{IU}$ of intravenous heparin administered during before AVF construction was associated with no benefit regarding AVF patency. However, there were significantly more bleeding events in the heparin group than those in the non-heparin group [72, 73].

A randomized trial of 115 patients demonstrated that systemic anticoagulation therapy, comprising 5000 IU of intravenous heparin administered during the perioperative stage of AVG construction could not prevent AVG thrombosis. Interestingly, the use of systemic anticoagulation therapy was associated with an increased risk of bleeding events [72]. In addition, a multicenter clinical study, in which 107 patients were randomly assigned to receive either low-intensity warfarin [target international normalized ratio, (INR) 1.51.9] or placebo after AVG construction, revealed that there was no difference in the time to VAF between the two groups (199 vs. 83 days, $P=\mathrm{NS}$ ). However, more bleeding events were noted in the warfarin group than those in the placebo group. Surprisingly, despite close INR monitoring, $10 \%$ of patients in the warfarin group developed major hemorrhage events [74].

Statins As shown in Table 5, the effect of statins on VAF has been controversial. the SHARP trial (Study of Heart and Renal Protection), the AURORA study (A

Table 5 The association of statins with VAF

\begin{tabular}{|c|c|c|c|c|c|}
\hline Author & Design & $\begin{array}{l}\mathrm{N} \\
(\text { Control })\end{array}$ & Exposure Timing & Outcome (duration) & VAF development \\
\hline $\begin{array}{l}\text { Wanner et al [79] } \\
\text { (4D study) }\end{array}$ & $\begin{array}{l}\text { Placebo- } \\
\text { controlled }\end{array}$ & $\begin{array}{l}1255 \\
(636)\end{array}$ & $\begin{array}{l}\text { Atorvastatin } \\
20 \mathrm{mg} / \text { day }\end{array}$ & $\begin{array}{l}\text { Incidence of cardiovascular events } \\
\text { ( } 4 \text { years) }\end{array}$ & NA \\
\hline $\begin{array}{l}\text { Fellstrom et al [78] } \\
\text { (AURORA trial) }\end{array}$ & $\begin{array}{l}\text { Placebo- } \\
\text { controlled }\end{array}$ & $\begin{array}{l}2776 \\
(1385)\end{array}$ & $\begin{array}{l}\text { Rosuvastatin } \\
10 \mathrm{mg} / \text { day } \\
\text { Pre }\end{array}$ & $\begin{array}{l}\text { Incidence of VA procedure ( } 3.8 \\
\text { years) }\end{array}$ & $\begin{array}{l}\text { Equivalent risk } \\
\text { (RR 1.10, 95\% Cl 0.95-1.27, } \\
P=0.19)\end{array}$ \\
\hline $\begin{array}{l}\text { Baigent et al [76] } \\
\text { (SHARP trial) }\end{array}$ & $\begin{array}{l}\text { Placebo- } \\
\text { controlled }\end{array}$ & $\begin{array}{l}9270 \\
(4620)\end{array}$ & $\begin{array}{l}\text { Simvastatin } \\
20 \text { mg/day } \\
+ \text { Ezetimibe } \\
10 \text { mg/day } \\
\text { Pre }\end{array}$ & $\begin{array}{l}\text { Incidence of VA occulusive events } \\
\text { (5 years) }\end{array}$ & $\begin{array}{l}\text { Unclear } \\
\text { (29.7\% vs. 33.5\%, RR 0.87, } \\
95 \% \text { Cl 0.75-1.00, P = 0.05) }\end{array}$ \\
\hline $\begin{array}{l}\text { Herrington et al }[75] \\
\text { (Combined analysis of AURORA \& } \\
\text { SHARP trial) }\end{array}$ & $\begin{array}{l}\text { Placebo- } \\
\text { controlled }\end{array}$ & $\begin{array}{l}1432 \\
(725)\end{array}$ & $\begin{array}{l}\text { Rosuvastatin } 10 \\
\text { mg/day } \\
\text { or } \\
\text { Simvastatin } \\
20 \text { mg/day } \\
+ \text { Ezetimibe } \\
10 \text { mg/day } \\
\text { Pre }\end{array}$ & $\begin{array}{l}\text { Incidence of VA occulusive events } \\
\text { ( } 4.5 \text { years) }\end{array}$ & $\begin{array}{l}\text { Equivalent risk } \\
(29.3 \% \text { vs. } 30.5 \%, \text { RR 0.95, } \\
95 \% \mathrm{Cl} 0.85-1.05, \mathrm{P}=0.29)\end{array}$ \\
\hline
\end{tabular}

VAF vascular access failure, $V A$ vascular access, $R R$ relative risk, $H R$ hazard ratio, $C$ confidential interval, Pre pre-operative period, $N A$ not available, $4 D$ Randomized controlled trial on the efficacy and safety of atorvastatin in patients with type 2 diabetes on hemodialysis, AURORA A Study to Evaluate the Use of Rosuvastatin in Subjects on Regular Hemodialysis: An Assessment of Survival and Cardiovascular Events, SHARP The Study of Heart and Renal Protection 
Study to Evaluate the Use of Rosuvastatin in Subjects on Regular Hemodialysis: An Assessment of Survival and Cardiovascular Events), and 4D study (Atorvastatin in patients with type 2 diabetes mellitus undergoing hemodialysis) are well-known large-scale clinical trials that examined the effects of statins on patients undergoing HD.

In the SHARP trial, 9270 patients with chronic kidney disease were randomly assigned to receive either simvastatin $(20 \mathrm{mg})$ and ezetimibe $(10 \mathrm{mg})$ or placebo before AVF construction; the results of this trial suggested that compared with placebo, lowering low-density lipoprotein cholesterol with statins improves VA patency (33.5\% vs. 29.7\%; RR 0.87, 95\% CI $0.75-1.00, P=0.05$ ) [76]. To further investigate the hypothesis suggested by the SHARP trial, a combined analysis of data from the SHARP and AURORA trials was performed. After combining the two trials, the overall effect on VAF events, following the reduction of low-density lipoprotein cholesterol with a statin-based regimen, was not statistically significant $(29.3 \%$ vs. $30.5 \%$; RR 0.95 , 95\% CI $0.85-1.05, P$ $=0.29)$ [75].

In the AURORA trial, 2776 patients were randomly assigned to receive either rosuvastatin $(10 \mathrm{mg})$ or placebo before AVF construction; the results demonstrated that statin treatment did not influence VA (RR 1.10, 95\% CI 0.95-1.27, $P=0.19$ ) [78].

In 2005, a large randomized controlled trial $(n=$ 1255) evaluating the efficacy and safety of atorvastatin in patients with type 2 diabetes undergoing HD (4D Study) [79] revealed that atorvastatin had no significant beneficial effect on the primary end-points such as cardiovascular death, nonfatal myocardial infarction, and stroke. However, the efficacy of atorvastatin for the prevention of VAF was not assessed in this trial or related sub-group analyses.

Fish oil As shown in Table 6, the effect of fish oil on VAF has been controversial. A multicenter, randomized controlled study involving 567 patients who received $4 \mathrm{~g}$ of fish oil or placebo every day prior to AVF construction demonstrated no significant difference in the incidence of VAF after 12 months between the two groups (22\% vs. $23 \%$; RR $0.98,95 \%$ CI $0.72-1.34, P=0.90)$. In addition, secondary outcomes such as thrombosis, the abandonment of AVF, and cannulation failure did not significantly differ between the two groups [68]. Conversely, a multicenter, randomized controlled trial on 201 patients who received $4 \mathrm{~g}$ of fish oil or placebo daily before AVG construction demonstrated that fish oil reduced the rate of AVG failure (3.43\% vs. 5.95\%; HR 0.58, 95\% CI $0.44-$ $0.75, P<0.001)$. In addition, secondary outcomes such as thrombosis $(3.41 \%$ vs. $1.71 \%)$ and VA intervention $(4.92 \%$ vs. $2.89 \%)$ were lower in the fish oil group than those in the placebo group [80].

Antihypertensive drugs As shown in Table 7, reninangiotensin system inhibitors (RAS-I) could be useful for the prevention of VAF. several studies evaluated the effects of antihypertensive drugs, such as reninangiotensin system inhibitors (RAS-I), on VAF. A large retrospective study enrolled 42,244 patients (AVFs $89.4 \%$, AVGs 10.6\%) to determine the effects of antihypertensive drugs on long-term VA patency. In this study, angiotensin-converting enzyme inhibitors (ACE-I), angiotensin receptor blockers (ARB), and calcium channel blockers (CCB) were eligible for analysis owing to their cardioprotective effects. The results of the aforementioned study showed that the use of ACE-I, ARB, and CCB were associated with prolonged primary AVF patency (HR 0.586, 0.532, and 0.485 for ACE-I, ARB, and CCB, respectively) and AVGs (HR 0.557, 0.536, and 0.482 for ACE-I, ARB, and CCB, respectively) [82]. These results indicated that RAS-I can be useful for the prevention of VAF.

However, a secondary analysis of data from the HEMO (Effect of dialysis dose and membrane flux in maintenance hemodialysis) study [87] demonstrated an association between an increased risk of VAF and

Table 6 The association of fish oil with VAF

\begin{tabular}{|c|c|c|c|c|c|}
\hline Author & Design & $\mathrm{N}$ (Control) & Exposure Timing & Outcome (duration) & VAF development \\
\hline Schmitz et al [81] & Placebo-controlled & $24(12)$ & $\begin{array}{l}\text { Omega-3 } \\
4 \text { g/day } \\
\text { Post }\end{array}$ & Primary patency rates of AVG (1 year) & $\begin{array}{l}\text { Lower risk } \\
(75.6 \% \text { vs. } 14.9 \%, \\
P<0.03)\end{array}$ \\
\hline Lok et al [80] & Placebo-controlled & $201(100)$ & $\begin{array}{l}\text { Omega-3 } \\
4 \mathrm{~g} / \text { day } \\
\text { Post }\end{array}$ & Primary AVG failure (1000 days) & $\begin{array}{l}\text { Lower risk } \\
\text { (3.43\% vs. 5.95\%, HR 0.58, } \\
95 \% \text { Cl } 0.44-0.75, \text { P < } 0.001\end{array}$ \\
\hline Irish et al [68] & Placebo-controlled & $567(283)$ & $\begin{array}{l}\text { Omega-3 } \\
4 \text { g/day } \\
\text { Pre }\end{array}$ & Primary AVF failure (12 months) & $\begin{array}{l}\text { Equivalent risk } \\
(22 \% \text { vs. } 23 \%, \mathrm{RR} 0.98,95 \% \\
\mathrm{Cl} 0.72-1.34, \mathrm{P}=0.90)\end{array}$ \\
\hline
\end{tabular}

VAF vascular access failure, VA vascular access, AVF arteriovenous fistula, AVG arteriovenous graft, $R R$ relative risk, $H R$ hazard ratio, $C I$ confidential interval, Pre preoperative period, Post post-operative period 
Table 7 The association of antihypertensive drugs with VAF

\begin{tabular}{|c|c|c|c|c|c|}
\hline Author & Design & N (Control) & Exposure Timing & Outcome (duration) & VAF development \\
\hline Gradzki et al [84] & Retrospective & $121(96)$ & $\begin{array}{l}\text { ACE-I } \\
\text { Various }\end{array}$ & $\begin{array}{l}\text { Primary AVG failure } \\
(1 \text { month to } 5 \text { years) }\end{array}$ & $\begin{array}{l}\text { Lower risk } \\
(\text { HR } 0.47,95 \% \text { Cl 0.23-0.93, } \\
P<0.03)\end{array}$ \\
\hline Sajgure et al [83] & Retrospective & $266(142)$ & $\begin{array}{l}\text { ACE-I } \\
\text { Various }\end{array}$ & Time to AVG failure & $\begin{array}{l}\text { Lower risk } \\
(671 \text { vs. } 459 \text { days, } P=0.012)\end{array}$ \\
\hline Jackson et al [85] & Retrospective & $332(263)$ & $\begin{array}{l}\text { ARB } \\
\text { Various }\end{array}$ & $\begin{array}{l}\text { Primary patency rates } \\
\text { of VA ( } 2 \text { years) }\end{array}$ & $\begin{array}{l}\text { Lower risk } \\
\text { (AVF: HR } 0.35,95 \% \mathrm{Cl} 0.16-0.76, P=0.08 \text { ) } \\
\text { (AVG: HR } 0.41,95 \% \mathrm{Cl} 0.18-0.95, P=0.039 \text { ) }\end{array}$ \\
\hline Chen et al [82] & Retrospective & $42244(18480)$ & $\begin{array}{l}\text { ACE-I } \\
\text { ARB } \\
\text { CCB } \\
\text { Various }\end{array}$ & $\begin{array}{l}\text { Primary patency rates } \\
\text { of VA }\end{array}$ & $\begin{array}{l}\text { Lower risk } \\
\text { (AVF: HR } 0.586 \text { for ACE-I, } 0.532 \text { for ARB, } \\
0.485 \text { for CCB) } \\
\text { (AVG: HR } 0.557 \text { for ACE-I, } 0.536 \text { for } A R B \text {, } \\
0.482 \text { for CCB) }\end{array}$ \\
\hline
\end{tabular}

VAF vascular access failure, $V A$ vascular access, $A V G$ arteriovenous graft, $H R$ hazard ratio, $C l$ confidential interval

frequent episodes of intradialytic hypotension and lower predialysis systolic blood pressure [88].

\section{Maintenance of VA}

Maintenance of VA plays an important role for preventing VAF after VA construction. According to various guidelines, in particular, blood pressure management during HD, monitoring, and surveillance, which we review and focus on these points in this chapter, are important.

\section{Blood pressure management}

JSDT guidelines suggest that hypotension is one of risk factors of VA occlusion [8], and several studies indicated the association between hypotension and VAF.

A secondary analysis of data from the HEMO study aiming to identify risk factors of VAF was performed [88]. This study examined whether frequent episodes of hypotension and blood pressure fluctuation during HD were associated with VAF 1426 patients undergoing HD. In AVFs, patients undergoing HD with frequent episodes of intradialytic hypotension had a higher incidence of AVF thrombosis (RR 2.02, 95\% CI $1.22-3.35, \quad P<0.01)$. Whereas in AVGs, patients undergoing HD with higher predialysis systolic blood pressure had a lower incidence of AVG thrombosis (RR 0.88, 95\% CI 0.80-0.97, $P<0.01$ ) [88].

Table 8 Monitoring and surveillance for VAF

- Physical examination

- Blood flow measurement (AVF: monthly, AVG: every 3 months)

- Ultrasound examination of VA at regular intervals

- Venous pressure measurement

- Pre-emptive balloon angioplasty to prevent VAF

$V A F$ vascular access failure, $A V F$ arteriovenous fistula, $A V G$ arteriovenous graft, $V A$ vascular access
An observational study enrolled 463 patients undergoing HD to examine the risk factors affecting AVF patency during 5 years of follow-up. In this study, patients with early AVF failure were excluded from the analysis $(P=0.002)$. Episodes of hypotension were defined as systolic pressure of $<110 \mathrm{mmHg}$ and diastolic pressure of $<70 \mathrm{mmHg}$ before the start of HD. In patients with hypertension, a decrease by $>30 \%$ of blood pressure was defined as relative hypotension. During ten consecutive HD sessions, 218 patients experienced at least one episode of hypotension. This study demonstrated that the lowest mean diastolic pressure had significantly lower patency rates of AVF $(P=0.045)$ than that of the mean diastolic pressure, whereas the lowest mean systolic pressure had no effect $(P=0.624)$ [89]. Considering that blood pressure fluctuation during HD was associated with VAF, appropriate blood pressure management during HD could be crucial for prevention of VAF.

\section{Monitoring and surveillance}

As shown in Table 8, several guidelines recommend both monitoring and surveillance to facilitate the early detection of VAF after VA construction $[8,10,15]$.

Vascular access nurse VA nurses, also called VA coordinators or VA managers, play a crucial role in the prevention of VAF. As shown in Table 9, they have various responsibilities to manage $\mathrm{VA}$ and prevent

Table 9 Responsibilities of VA nurses

- Coordinating the VA nurse team work

- Preparation and education for patients with VA construction

- Communication with the VA surgeon or interventional nephrologists

- Evaluation of the first cannulation

- VA monitoring with physical examination

VA vascular access 


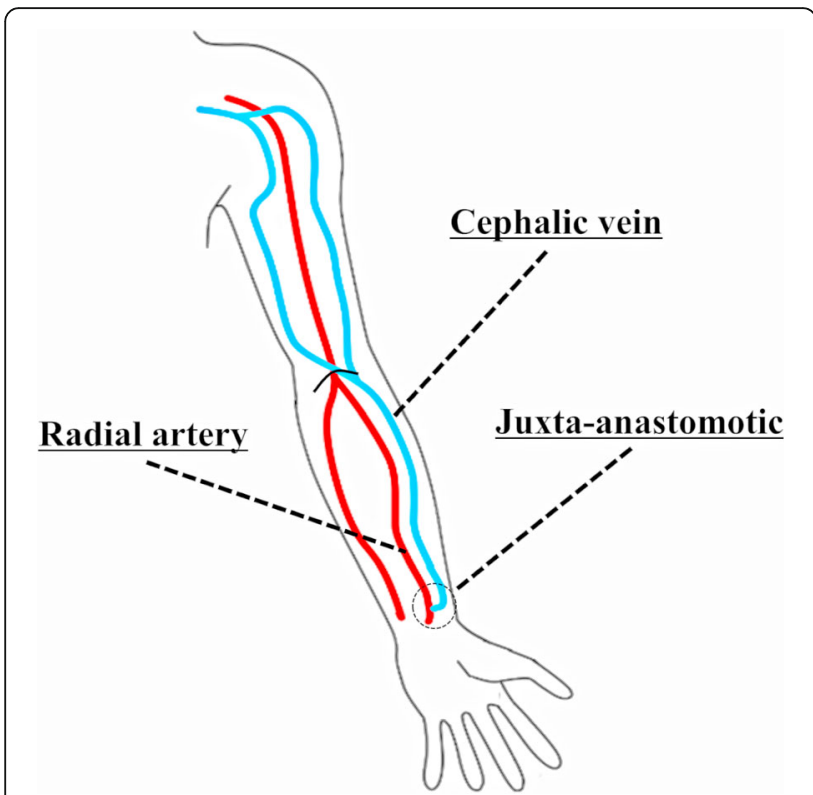

Fig. 1 Stenosis distribution of arteriovenous fistula (AVF). Stenosis distribution in a typical AVF constructed by anastomosing the radial artery to the cephalic vein. The frequent stenotic sites of arteriovenous fistula are juxta-anastomotic (64\%), cephalic vein (20\%), and inflow artery (6\%)
VAF. An aggressive, multidisciplinary access program conducted by VA nurses is recommended by ERBP (Grade C1) and European Society for Vascular Surgery (ESVS) guidelines (Class IIa) [9, 15].

Several studies have reported that VA coordinators could significantly increase the proportion of AVF in newly constructed VA [90, 91]. Furthermore, an observational study of $450 \mathrm{HD}$ patients revealed that VA coordinators could markedly reduce surgical complications during AVG construction by $14 \%$ and decrease the incidence of AVG thrombosis by $60 \%$ [92].

Monitoring Physical examinations are useful for early detection of VAF. Three components for VA examination are recommended by guidelines: inspection, palpation, and auscultation [8, 10, 15]. Abnormalities of physical examination, such as extremity edema, alterations in the pulse, thrill, or bruit, may be associated with impending VAF.

On the other hand, ultrasound examination is a non-invasive and effective apparatus that provides beneficial information for the monitoring of VA, as well as a tool for preoperative vascular imaging. In particular, blood flow of VA was estimated by measuring the brachial artery volume flow using ultrasound examination. VAF should be suspected when blood flow is less than $500 \mathrm{ml} / \mathrm{min}$ (JDST, ESVS) or less than $400-500 \mathrm{ml} / \mathrm{min}$ (K/DOQI) in AVFs $[8,10$,

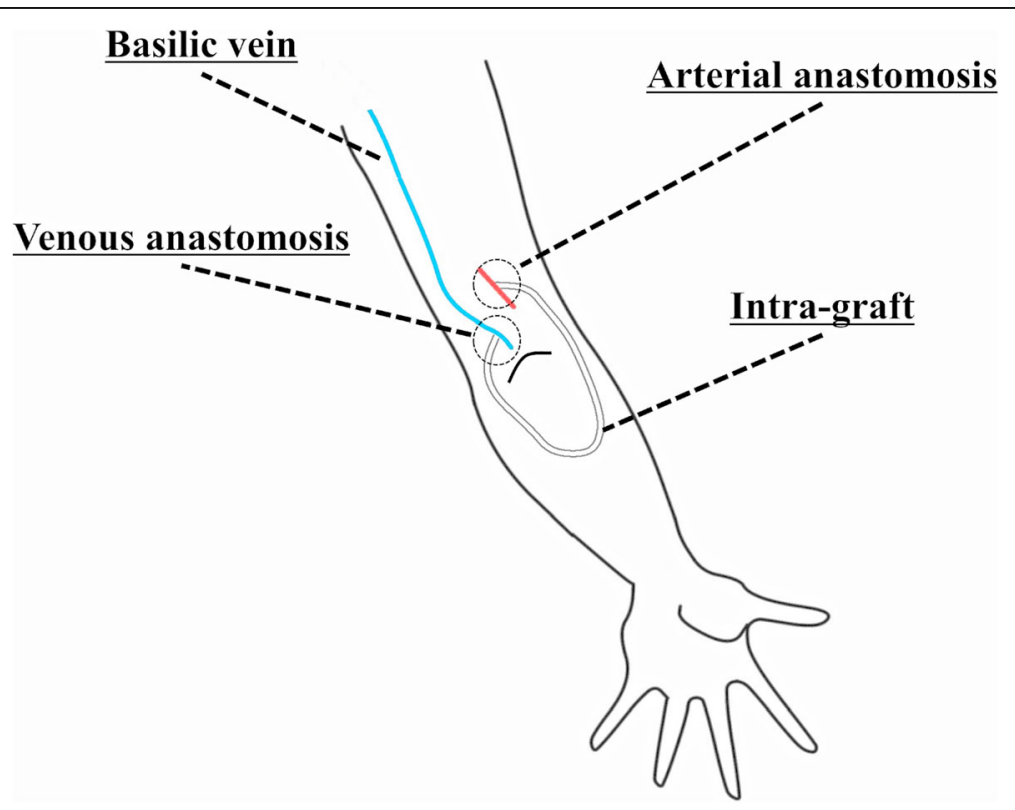

Fig. 2 Stenosis distribution of arteriovenous graft (AVG). Stenosis distribution in a typical looped-upper arm AVG constructed between the brachial artery and brachial vein. The frequent stenotic sites of AVG are venous anastomosis (47\%), basilic vein (27\%), arterial anastomosis (4\%), and intra-graft (2\%) 


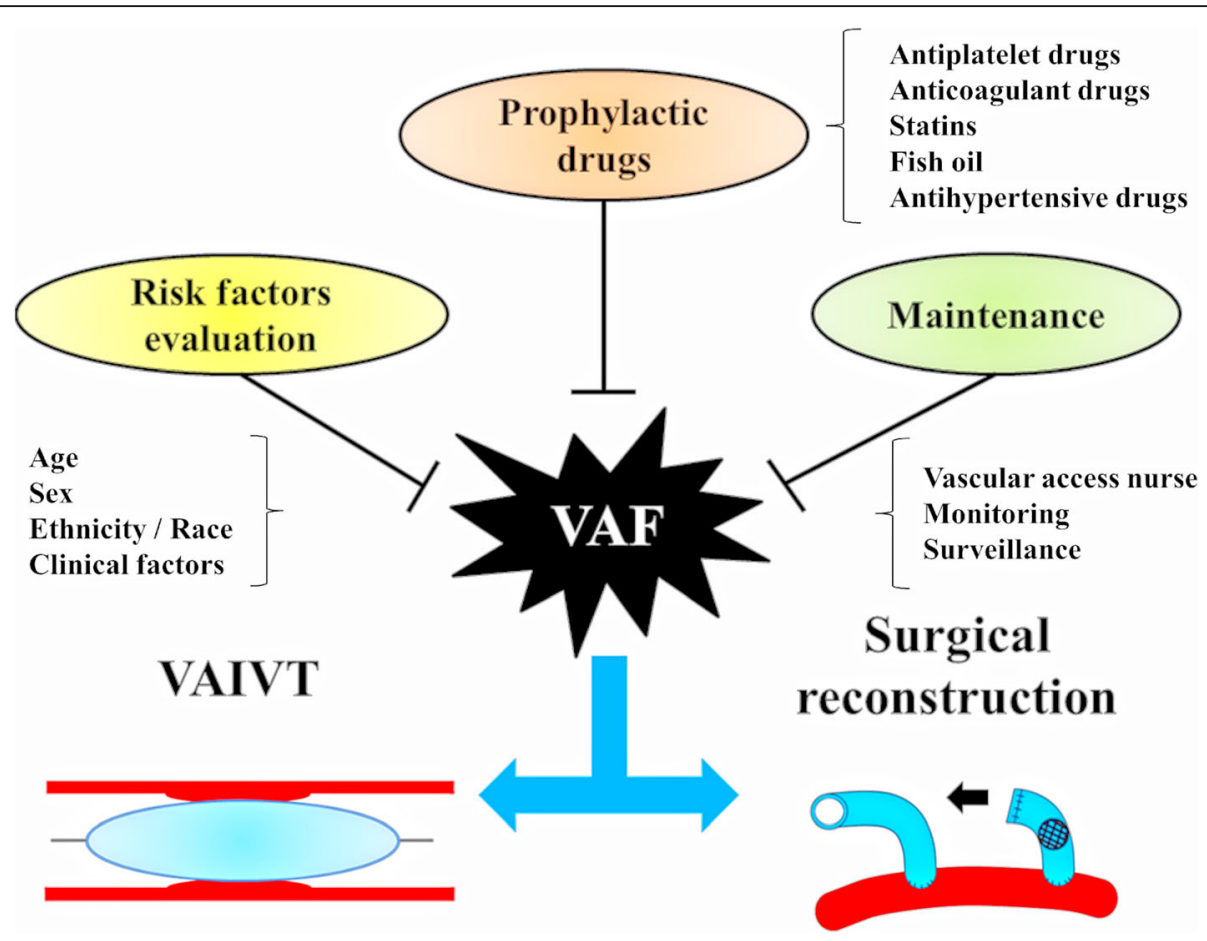

Fig. 3 Prevention and treatment of vascular access failure (VAF). VAF could occur during vascular access (VA) construction, VA maturation, or maintenance phase. Firstly, the risk factors of VAF must be evaluated. For early detection of VAF, monitoring and surveillance of VA are essential. Although there have been no reports of prophylactic drugs with strong efficacy for preventing VAF, such drugs could be effective in any phase. Either VAIVT or surgical reconstruction must be selected when VAF occurs. Particularly, surgical reconstruction in a proximal region could be possible, especially if VAF occurs as a result of thrombotic occlusion. Surgical reconstruction implies the relocation of the anastomosis to a proximal site

15], although there is no clear definition of maturation. Besides, an observational study of 101 AVFs was performed to evaluate the association between adequate AVF rates and risk factors of VAF. In this study, AVF was defined as adequate for HD when the AVF was successfully cannulated over a period of at least six HD sessions in a month, and AVF was required a blood flow of at least a consistent $350 \mathrm{ml} / \mathrm{min}$ [28]. This study was cited in ESVS guidelines; this guidelines suggest that cannulation of VA is not preferred when the quantity of blood flow is less than $350 \mathrm{ml} / \mathrm{min}$, although the levels of evidence are not high [15].

Surveillance at frequent stenotic site As shown in Fig. 1, the highest incidence of AVF stenosis was noted within $3 \mathrm{~cm}$ of the anastomosis site [93]. VAF due to stenosis or thrombosis is more commonly associated with AVG than with AVF. A randomized, double-blind, placebo-controlled trial revealed that > $90 \%$ of thrombosed AVGs exhibited a stenotic lesion [62]. In AVGs, stenosis most commonly occurred in the outflow vessel of the access, i.e., the site of venous anastomosis. As shown in Fig. 2, a retrospective observational study revealed that $47 \%$ of AVG stenosis occurred at the site of venous anastomosis, and $11 \%$ occurred within $1 \mathrm{~cm}$ of the anastomosis site in a typical looped-upper arm AVG [94].

\section{Conclusions}

In this review, we summarized the available literatures regarding the prevention of VAF in patients with HD with a focus on AVFs and AVGs. As shown in Fig. 3, this review supports the use of the following three aspects for developing strategies for preventing VAF: (i) early identification of risk factors of VAF (e.g., preoperative vascular conditions, age, sex, ethnicity, and clinical backgrounds), (ii) prophylactic drugs to reduce the risk of VAF, and (iii) early VAF detection through monitoring and surveillance of VA, particularly at frequent stenotic sites. In particular, some prophylactic drugs may be effective for the prevention of VAF based on the patient's clinical background or the type of VA used. However, there are no prophylactic drugs that can be potentially used for reducing the incidence of VAF. Therefore, further large, randomized placebo-controlled studies are warranted to support the development of effective strategies for preventing VAF. 


\section{Abbreviations}

4D Study: Randomized controlled trial on the efficacy and safety of atorvastatin in patients with type 2 diabetes on hemodialysis; ABI: Anklebrachial index; ACE-l: Angiotensin-converting enzyme inhibitor:

ARB: Angiotensin receptor blocker; AURORA Study: A Study to Evaluate the Use of Rosuvastatin in Subjects on Regular Hemodialysis: An Assessment of Survival and Cardiovascular Events; AVFs: Arteriovenous fistulas; AVGs: Arteriovenous grafts; BMI: Body mass index; CAD: Coronary artery disease; CCB: Calcium channel blocker; ERBP: European Renal Best Practice Guidelines; ESRD: End-stage renal disease; ESVS: European Society for Vascular Surgery guidelines; HD: Hemodialysis; INR: International normalized ratio; JSDT: Japanese Society for Dialysis Therapy; K/DOQI: United States Kidney Disease Outcomes Quality Initiative; MPV: Mean platelet volume; NS: Not significant; PAD: Peripheral artery disease; RAS-I: Renin-angiotensin system inhibitor; RRT: Renal replacement therapy; SHARP Study: The Study of Heart and Renal Protection; US: United States; USRDS: United States Renal Data System; VA: Vascular access; VAF: Vascular access failure

\section{Acknowledgments}

The authors would like to thank Enago (www.enago.jp) for the English language review.

\section{Funding}

Not applicable.

Availability of data and materials

Not applicable.

\section{Authors' contributions}

All authors have read and approved the final manuscript.

\section{Authors' information}

$H T, M N, T M, N S$, and MN are members of Division of Nephrology and Endocrinology at the University of Tokyo hospital.

\section{Ethics approval and consent to participate}

Not applicable.

\section{Consent for publication}

Not applicable.

\section{Competing interests}

The authors declare that they have no competing interests.

\section{Publisher's Note}

Springer Nature remains neutral with regard to jurisdictional claims in published maps and institutional affiliations.

\section{Received: 6 December 2018 Accepted: 28 March 2019} Published online: 21 May 2019

\section{References}

1. Ravani P, Palmer SC, Oliver MJ, Quinn RR, MacRae JM, Tai DJ, et al. Associations between hemodialysis access type and clinical outcomes: a systematic review. J Am Soc Nephrol. 2013;24(3):465-73.

2. Stracke S, Konner K, Köstlin I, Friedl R, Jehle PM, Hombach V, Waltenberger J, et al. Increased expression of TGF-beta1 and IGF-I in inflammatory stenotic lesions of hemodialysis fistulas. Kidney Int. 2002:61(3):1011-9.

3. Rekhter M, Nicholls S, Ferguson M, Gordon D. Cell proliferation in human arteriovenous fistulas used for hemodialysis. Arterioscler Thromb. 1993;13(4):609-17.

4. Hsieh HJ, Li NQ, Frangos JA. Shear stress increases endothelial plateletderived growth factor mRNA levels. Am J Physiol. 1991;260(2 Pt2):H642-6.

5. Sterpetti AV, Cucina A, Santoro L, Cardillo B, Cavallaro A. Modulation of arterial smooth muscle cell growth by haemodynamic forces. Eur J Vasc Surg. 1992;6(1):16-20.

6. Hofstra L, Bergmans DC, Hoeks AP, Kitslaar PJ, Leunissen KM, et al. Mismatch in elastic properties around anastomoses of interposition grafts for hemodialysis access. J Am Soc Nephrol. 1994;5(5):1243-50.

7. Himmelfarb J. Pharmacologic prevention of vascular access stenosis. Curr Opin Nephrol Hypertens. 1999;8(5):569-72.
8. Kukita K, Ohira S, Amano I, Naito H, Azuma N, Ikeda K, Vascular Access Construction and Repair for Chronic Hemodialysis Guideline Working Group, Japanese Society for Dialysis Therapy, et al. 2011 update Japanese Society for Dialysis Therapy Guidelines of Vascular Access Construction and Repair for Chronic Hemodialysis. Ther Apher Dial. 2015;19(Suppl 1):1-39.

9. Renal Association 6th Edition (2015). https://renal.org/wp-content/uploads/ 2017/06/vascular-access.pdf. Accessed 1 Dec 2018.

10. United States Renal Data System. 2018 annual data report. https://www.usrds. org/2018/download/v2_c01_IncPrev_18_slides.pptx. Accessed 1 Dec 2018.

11. Feldman $\mathrm{HI}$, Kobrin S, Wasserstein A. Hemodialysis vascular access morbidity. J Am Soc Nephrol. 1996;7(4):523-35.

12. Manns B, Tonelli M, Yilmaz S, Lee H, Laupland K, Klarenbach S, et al. Establishment and maintenance of vascular access in incident hemodialysis patients: a prospective cost analysis. J Am Soc Nephrol. 2005;16(1):201-9.

13. The Japanese Society for Dialysis Therapy. https://docs.jsdt.or.jp/overview/ pdf2017/p007.pdf. Accessed 1 Dec 2018.

14. Lomonte C, Basile C, Mitra S, Combe C, Covic A, Davenport A, et al. Should a fistula first policy be revisited in elderly haemodialysis patients? Nephrol Dial Transplant. 2018 Oct 17. https://doi.org/10.1093/ndt/gfy319.

15. Schmidli J, Widmer MK, Basile C, de Donato G, Gallieni M, Gibbons CP, et al. Esvs guidelines reviewers, Mohaupt M, Ricco JB, Roca-Tey R. Editor's choice — vascular access: 2018 clinical practice guidelines of the European Society for Vascular Surgery (ESVS). Eur J Vasc Endovasc Surg. 2018;55(6):757-818.

16. Lin SL, Huang CH, Chen HS, Hsu WA, Yen CJ, Yen TS. Effects of age and diabetes on blood flow rate and primary outcome of newly created hemodialysis arteriovenous fistulas. Am J Nephrol. 1998;18(2):96-100.

17. Lok CE, Allon M, Moist L, Oliver MJ, Shah H, Zimmerman D. Risk equation determining unsuccessful cannulation events and failure to maturation in arteriovenous fistulas (REDUCE FTM I). J Am Soc Nephrol. 2006;17(11):3204-12.

18. Huijbregts HJ, Bots ML, Wittens CH, Schrama YC, Moll FL. Blankestijn PJ; CIMINO study group. Hemodialysis arteriovenous fistula patency revisited: results of a prospective, multicenter initiative. Clin J Am Soc Nephrol. 2008;3(3):714-9.

19. Beaulieu MC, Dumaine CS, Romann A, Kiaii M. Advanced age is not a barrier to creating a functional arteriovenous fistula: a retrospective study. J Vasc Access. 2017;18(4):307-12.

20. Lazarides MK, Georgiadis GS, Antoniou GA, Staramos DN. A meta-analysis of dialysis access outcome in elderly patients. J Vasc Surg. 2007;45(2):420-426.

21. Lok CE, Oliver M, Su J, Bhola C, Hannigan N, Jassal SV. Arteriovenous fistula outcomes in the era of the elderly dialysis population. Kidney Int. 2005;67(6):2462-9.

22. Peterson WJ, Barker J, Allon M. Disparities in fistula maturation persist despite preoperative vascular mapping. Clin J Am Soc Nephrol. 2008;3(2):437-41.

23. Hod T, Desilva RN, Patibandla BK, Vin Y, Brown RS, Goldfarb-Rumyantzev AS. Factors predicting failure of AV "fistula first" policy in the elderly. Hemodial Int. 2014;18(2):507-15.

24. Marcus RJ, Marcus DA, Sureshkumar KK, Hussain SM, McGill RL. Gender differences in vascular access in hemodialysis patients in the United States: developing strategies for improving access outcome. Gend Med. 2007;4(3):193-204.

25. Woo K, Gascue L, Goldman DP, Romley JA. Variations in outcomes of hemodialysis vascular access by race/ethnicity in the elderly. J Vasc Surg. 2017;65(3):783-92

26. Gibson KD, Caps MT, Kohler TR, Hatsukami TS, Gillen DL, Aldassy M, et al. Assessment of a policy to reduce placement of prosthetic hemodialysis access. Kidney Int. 2001;59(6):2335-45.

27. Wilmink T, Wijewardane A, Lee K, Murley A, Hollingworth L, Powers S, et al. Effect of ethnicity and socioeconomic status on vascular access provision and performance in an urban NHS hospital. Clin Kidney J. 2017;10(1):62-7.

28. Miller PE, Tolwani A, Luscy CP, Deierhoi MH, Bailey R, Redden DT, et al. Predictors of adequacy of arteriovenous fistulas in hemodialysis patients. Kidney Int. 1999;56(1):275-80.

29. Qiao Y, Suri FK, Zhang Y, Liu L, Gottesman R, Alonso A, Guallar E, Wasserman BA. Racial Differences in Prevalence and Risk for Intracranial Atherosclerosis in a US Community-Based Population. JAMA Cardiol. 2017;2(12):1341-1348.

30. Dluzen DF, Noren Hooten N, Zhang Y, Kim Y, Glover FE, Tajuddin SM, Jacob $K D$, Zonderman $A B$, Evans MK. Racial differences in microRNA and gene expression in hypertensive women. Sci Rep. 2016;6:35815.

31. Feairheller DL, Park JY, Sturgeon KM, Williamson ST, Diaz KM, Veerabhadrappa P, Brown MD. Racial differences in oxidative stress and inflammation: in vitro and in vivo. Clin Transl Sci. 2011:4(1):32-7.

32. Marchesi S, Lupattelli G, Sensini A, Lombardini R, Brozzetti M, Roscini AR, Siepi D, Mannarino E, Vaudo G. Racial difference in endothelial function: role of the infective burden. Atherosclerosis. 2007;191(1):227-34. 
33. Wu CK, Lin CH, Hsu CC, Tarng DC, Kor CT, Chen YC, et al. Association of early loss of primary functional patency of arteriovenous access with mortality in incident hemodialysis patients: a nationwide population-based observational study. Medicine (Baltimore). 2018;97(31):e11630.

34. Azab B, Torbey E, Singh J, Akerman M, Khoueiry G, McGinn JT, et al. Mean platelet volume/platelet count ratio as a predictor of long-term mortality after non-ST-elevation myocardial infarction. Platelets. 2011;22(8):557-66.

35. Shin DH, Rhee SY, Jeon HJ, Park JY, Kang SW, Oh J. An increase in mean platelet volume/platelet count ratio is associated with vascular access failure in hemodialysis patients. PLoS One. 2017;12(1):e0170357.

36. Dixon BS. Why don't fistulas mature? Kidney Int. 2006;70(8):1413-22.

37. Woods JD, Turenne MN, Strawderman RL, Young EW, Hirth RA, Port FK, et al. Vascular access survival among incident hemodialysis patients in the United States. Am J Kidney Dis. 1997;30(1):50-7.

38. Chen SC, Chang JM, Hwang SJ, Tsai JC, Wang CS, Mai HC, et al. Significant correlation between ankle-brachial index and vascular access failure in hemodialysis patients. Clin J Am Soc Nephrol. 2009;4(1):128-34.

39. Field M, MacNamara K, Bailey G, Jaipersad A, Morgan RH, Pherwani AD. Primary patency rates of AV fistulas and the effect of patient variables. J Vasc Access. 2008;9(1):45-50.

40. Sedlacek M, Teodorescu V, Falk A, Vassalotti JA, Uribarri J. Hemodialysis access placement with preoperative noninvasive vascular mapping: comparison between patients with and without diabetes. Am J Kidney Dis. 2001;38(3):560-4.

41. Allon M, Ornt DB, Schwab SJ, Rasmussen C, Delmez JA, Greene T, et al. Factors associated with the prevalence of arteriovenous fistulas in hemodialysis patients in the HEMO study. Hemodialysis (HEMO) study group. Kidney Int. 2000;58(5):2178-85.

42. Chan MR, Young HN, Becker YT, Yevzlin AS. Obesity as a predictor of vascular access outcomes: analysis of the USRDS DMMS Wave II study. Semin Dial. 2008;21(3):274-9.

43. Kats M, Hawxby AM, Barker J, Allon M. Impact of obesity on arteriovenous fistula outcomes in dialysis patients. Kidney Int. 2007;71(1):39-43.

44. Plumb TJ, Adelson AB, Groggel GC, Johanning JM, Lynch TG, Lund B. Obesity and hemodialysis vascular access failure. Am J Kidney Dis. 2007;50(3):450-4

45. Lomonte C, Basile C. Preoperative assessment and planning of haemodialysis vascular access. Clin Kidney J. 2015;8(3):278-81.

46. Singh $\mathrm{P}$, Robbin ML, Lockhart ME, Allon M. Clinically immature arteriovenous hemodialysis fistulas: effect of US on salvage. Radiology. 2008; 246(1):299-305.

47. Bourquelot P, Tawakol JB, Gaudric J, Natário A, Franco G, Turmel-Rodrigues $L$, et al. Lipectomy as a new approach to secondary procedure superficialization of direct autogenous forearm radial-cephalic arteriovenous accesses for hemodialysis. J Vasc Surg. 2009;50(2):369-74.

48. Krochmal DJ, Rebecca AM, Kalkbrenner KA, Casey WJ, Fowl RJ, Stone WM, et al. Superficialization of deep arteriovenous access procedures in obese patients using suction-assisted lipectomy: a novel approach. Can J Plast Surg. 2010;18(1):25-7.

49. Roberts C. Saving a brachiocephalic fistula using lipectomy. Nephrol Nurs J. 2005;32(3):331.

50. Barnard KJ, Taubman KE, Jennings WC. Accessible autogenous vascular access for hemodialysis in obese individuals using lipectomy. Am J Surg 2010;200(6):798-802.

51. Sidawy AN, Gray R, Besarab A, Henry M, Ascher E, Silva M Jr, et al. Recommended standards for reports dealing with arteriovenous hemodialysis accesses. J Vasc Surg. 2002;35(3):603-10.

52. Paul BZ, Feeney CM. Combining the modified Allen's test and pulse oximetry for evaluating ulnar collateral circulation to the hand for radial artery catheterization of the ED patient. Cal J Emerg Med. 2003;4(4):89-91.

53. Silva MB Jr, Hobson RW 2nd, Pappas PJ, Jamil Z, Araki CT, Goldberg MC, et al. A strategy for increasing use of autogenous hemodialysis access procedures: impact of preoperative noninvasive evaluation. J Vasc Surg. 1998;27(2):302-7.

54. Parmar J, Aslam M, Standfield N. Pre-operative radial arterial diameter predicts early failure of arteriovenous fistula (AVF) for haemodialysis. Eur J Vasc Endovasc Surg. 2007;33(1):113-5

55. Malovrh M. Native arteriovenous fistula: preoperative evaluation. Am J Kidney Dis. 2002;39(6):1218-25.

56. Allon M, Greene T, Dember LM, Vita JA, Cheung AK, Hamburg NM, et al. Hemodialysis fistula maturation study group. Association between preoperative vascular function and postoperative arteriovenous fistula development. J Am Soc Nephrol. 2016;27(12):3788-95.
57. Lee T, Safdar N, Mistry MJ, Wang Y, Chauhan V, Campos B, et al. Preexisting venous calcification prior to dialysis vascular access surgery. Semin Dial. 2012;25(5):592-5.

58. Lee T, Chauhan V, Krishnamoorthy M, Wang Y, Arend L, Mistry MJ, et al. Severe venous neointimal hyperplasia prior to dialysis access surgery. Nephrol Dial Transplant. 2011;26(7):2264-70.

59. Jemcov TK. Morphologic and functional vessels characteristics assessed by ultrasonography for prediction of radiocephalic fistula maturation. J Vasc Access. 2013;14(4):356-63.

60. van der Linden J, Lameris TW, van den Meiracker AH, de Smet AA, Blankestijn PJ, van den Dorpel MA. Forearm venous distensibility predicts successful arteriovenous fistula. Am J Kidney Dis. 2006;47(6):1013-9.

61. Kim JT, Chang WH, Oh TY, Jeong YK. Venous distensibility as a key factor in the success of arteriovenous fistulas at the wrist. Ann Vasc Surg. 2011;25(8):1094-8.

62. Dixon BS, Beck GJ, Vazquez MA, Greenberg A, Delmez JA, Allon M, DAC Study Group, et al. Effect of dipyridamole plus aspirin on hemodialysis graft patency. N Engl J Med. 2009;360(21):2191-201.

63. Trimarchi H, Young P, Forrester M, Schropp J, Pereyra H, Freixas E. Clopidogrel diminishes hemodialysis access graft thrombosis. Nephron Clin Pract. 2006;102(3-4):c128-32.

64. Kaufman JS, O'Connor TZ, Zhang JH, Cronin RE, Fiore LD, Ganz MB, Veterans Affairs Cooperative Study Group on Hemodialysis Access Graft Thrombosis, et al. Randomized controlled trial of clopidogrel plus aspirin to prevent hemodialysis access graft thrombosis. J Am Soc Nephrol. 2003;14(9):2313-21.

65. Sreedhara R, Himmelfarb J, Lazarus JM, Hakim RM. Anti-platelet therapy in graft thrombosis: results of a prospective, randomized, double-blind study Kidney Int. 1994;45(5):1477-83.

66. Harter HR, Burch JW, Majerus PW, Stanford N, Delmez JA, Anderson CB, et al. Prevention of thrombosis in patients on hemodialysis by low-dose aspirin. N Engl J Med. 1979;301(11):577-9.

67. Russell TE, Kasper GC, Seiwert AJ, Comerota AJ, Lurie F. Cilostazol may improve maturation rates and durability of vascular access for hemodialysis. Vasc Endovasc Surg. 2017:51(3):120-4.

68. Irish AB, Viecelli AK, Hawley CM, Hooi LS, Pascoe EM, Paul-Brent PA, Omega-3 Fatty Acids (Fish Oils) and Aspirin in Vascular Access Outcomes in Renal Disease (FAVOURED) Study Collaborative Group, et al. Effect of fish oil supplementation and aspirin use on arteriovenous fistula failure in patients requiring hemodialysis: a randomized clinical trial. JAMA Intern Med. 2017;177(2):184-93.

69. Ghorbani A, Aalamshah M, Shahbazian H, Ehsanpour A, Aref A. Randomized controlled trial of clopidogrel to prevent primary arteriovenous fistula failure in hemodialysis patients. Indian J Nephrol. 2009;19(2):57-61.

70. Dember LM, Beck GJ, Allon M, Delmez JA, Dixon BS, Greenberg A, Dialysis Access Consortium Study Group, et al. Effect of clopidogrel on early failure of arteriovenous fistulas for hemodialysis: a randomized controlled trial. JAMA. 2008;299(18):2164-71.

71. Gröntoft KC, Larsson R, Mulec H, Weiss LG, Dickinson JP. Effects of ticlopidine in AV-fistula surgery in uremia. Fistula study group. Scand J Urol Nephrol. 1998;32(4):276-83.

72. D'Ayala M, Smith RM, Martone C, Briggs W, Deitch JS, Wise L. The effect of systemic anticoagulation in patients undergoing angioaccess surgery. Ann Vasc Surg. 2008;22(1):11-5.

73. Bhomi KK, Shrestha S, Bhattachan CL. Role of systemic anticoagulation in patients undergoing vascular access surgery. Nepal Med Coll J. 2008;10(4):222-4.

74. Crowther MA, Clase CM, Margetts PJ, Julian J, Lambert K, Sneath D, et al. Low-intensity warfarin is ineffective for the prevention of PTFE graft failure in patients on hemodialysis: a randomized controlled trial. J Am Soc Nephrol. 2002;13(9):2331-7.

75. Herrington W, Emberson J, Staplin N, Blackwell L, Fellström B, Walker R, SHARP Investigators, et al. The effect of lowering LDL cholesterol on vascular access patency: post hoc analysis of the study of heart and renal protection. Clin J Am Soc Nephrol. 2014;9(5):914-9.

76. Baigent C, Landray MJ, Reith C, Emberson J, Wheeler DC, Tomson C, SHARP Investigators, et al. The effects of lowering LDL cholesterol with simvastatin plus ezetimibe in patients with chronic kidney disease (study of heart and renal protection): a randomised placebo-controlled trial. Lancet. 2011; 377(9784):2181-92.

77. Pisoni R, Barker-Finkel J, Allo M. Statin therapy is not associated with improved vascular access outcomes. Clin J Am Soc Nephrol. 2010;5(8):1447-50.

78. Fellström BC, Jardine AG, Schmieder RE, Holdaas H, Bannister K, Beutler J, AURORA Study Group, et al. Rosuvastatin and cardiovascular events in patients undergoing hemodialysis. N Engl J Med. 2009;360(14):1395-407. 
79. Wanner C, Krane V, März W, Olschewski M, Mann JF, Ruf G, German Diabetes and Dialysis Study Investigators, et al. Atorvastatin in patients with type 2 diabetes mellitus undergoing hemodialysis. N Engl J Med. 2005;353(3):238-48.

80. Lok CE, Moist L, Hemmelgarn BR, Tonelli M, Vazquez MA, Dorval M, Oil Inhibition of Stenosis in Hemodialysis Grafts (FISH) Study Group, et al. Effect of fish oil supplementation on graft patency and cardiovascular events among patients with new synthetic arteriovenous hemodialysis grafts: a randomized controlled trial. JAMA. 2012;307(17):1809-16.

81. Schmitz PG, McCloud LK, Reikes ST, Leonard CL, Gellens ME. Prophylaxis of hemodialysis graft thrombosis with fish oil: double-blind, randomized, prospective trial. J Am Soc Nephrol. 2002;13(1):184-90.

82. Chen FA, Chien CC, Chen YW, Wu YT, Lin CC. Angiotensin convertingenzyme inhibitors, angiotensin receptor blockers, and calcium channel blockers are associated with prolonged vascular access patency in uremic patients undergoing hemodialysis. PLoS One. 2016:11(11):e0166362.

83. Sajgure A, Choudhury A, Ahmed Z, Choudhury D. Angiotensin converting enzyme inhibitors maintain polytetrafluroethylene graft patency. Nephrol Dial Transplant. 2007;22(5):1390-8.

84. Gradzki R, Dhingra RK, Port FK, Roys E, Weitzel WF, Messana JM. Use of ACE inhibitors is associated with prolonged survival of arteriovenous grafts. Am J Kidney Dis. 2001;38(6):1240-4.

85. Jackson RS, Sidawy AN, Amdur RL, Khetarpal A, Macsata RA. Angiotensin receptor blockers and antiplatelet agents are associated with improved primary patency after arteriovenous hemodialysis access placement. J Vasc Surg. 2011;54(6):1706-12.

86. Mizuno T, Nakamura M, Satoh N, Tsukada H, Matsumoto A, Hamasaki $Y$, et al. Patency with antiplatelet treatment after vascular access intervention therapy: a retrospective observational study doi: https://doi.org/10.1186/ s41100-018-0184-5.

87. Eknoyan G, Beck GJ, Cheung AK, Daugirdas JT, Greene T, Kusek JW, Hemodialysis (HEMO) Study Group, et al. Effect of dialysis dose and membrane flux in maintenance hemodialysis. N Engl J Med. 2002;347(25):2010-9.

88. Chang T1, Paik J, Greene T, Desai M, Bech F, Cheung AK, et al. Intradialytic hypotension and vascular access thrombosis. J Am Soc Nephrol. 2011;22(8):1526-33.

89. Puskar D, Pasini J, Savić I, Bedalov G, Sonicki Z. Survival of primary arteriovenous fistula in 463 patients on chronic hemodialysis. Croat Med J. 2002:43(3):306-11.

90. Polkinghorne KR, Seneviratne M, Kerr PG. Effect of a vascular access nurse coordinator to reduce central venous catheter use in incident hemodialysis patients: a quality improvement report. Am J Kidney Dis. 2009;53(1):99-106.

91. Dwyer A, Shelton P, Brier M, Aronoff G. A vascular access coordinator improves the prevalent fistula rate. Semin Dial. 2012;25(2):239-43.

92. Allon M, Bailey R, Ballard R, Deierhoi MH, Hamrick K, Oser R, Rhynes VK, Robbin ML, Saddekni S, Zeigler ST. A multidisciplinary approach to hemodialysis access: prospective evaluation. Kidney Int. 1998;53(2):473-9.

93. Rajan DK, Bunston S, Misra S, Pinto R, Lok CE. Dysfunctional autogenous hemodialysis fistulas: outcomes after angioplasty - are there clinical predictors of patency? Radiology. 2004;232(2):508-15

94. Kanterman RY, Vesely TM, Pilgram TK, Guy BW, Windus DW, Picus D. Dialysis access grafts: anatomic location of venous stenosis and results of angioplasty. Radiology. 1995;195(1):135-9.

Ready to submit your research? Choose BMC and benefit from:

- fast, convenient online submission

- thorough peer review by experienced researchers in your field

- rapid publication on acceptance

- support for research data, including large and complex data types

- gold Open Access which fosters wider collaboration and increased citations

- maximum visibility for your research: over $100 \mathrm{M}$ website views per year

At BMC, research is always in progress.

Learn more biomedcentral.com/submissions 